\title{
Clash of Civilizations or Clash of Religions?
}

Every phase of American foreign policy has found its supporters in American academia. The Cold War had its famous academicians who not only justified American foreign policy at that time but later became prominent decisionmakers. Henry Kissinger and Zbigniew Brzezinski are still remembered as successful academicians who became policymakers. However, only one prominent scholar has been able to survive the Cold War with his credibility intact while maintaining his influence on American foreign policy: Samuel P. Huntington.

In his recent article on "The Clash of Civilizations" (Foreign Affairs 77:3), Huntington attempts to predict the scenario of the New World Order that will have to be dealt with by the West. He then seeks to influence not only American foreign policy, but that of the entire West. His opening argument is that the old topology of conflict will be replaced by conflicts of civilizations. The world will be divided according to existing civilizations (i.e., western, Islamic, Confucianist, Hindu, Buddhist, Latin American, and possibly African). He then narrows the list of enemies to two civilizations: Confucianism and Islam. This short commentary will concentrate on the reasons behind Huntington's article in order to uncover the decay that is eating away at the beautiful face of the West.

\section{The Supremacy of Western Civilization}

From the beginning, Huntington attempts to convince the reader that the West represents a homogeneous culture. In addition, he infers that its culture and civilization is desired because it is superior and therefore natural for it to dominate. Here, he lacks the necessary credibility to provide a reason for such supremacy. Such a worldview is not new, for the same mentality helped to form similar justifications for western colonialism: "civilizing mission" and the "white man's burden" are the predecessors to Huntington's arguments.

Indirectly, Huntington calls upon the nonwestern world to join western civilization. He assumes that some nonwestern civilizations might accept western dominance faster and easier than others. The obstacles for joining, which are most difficult for Islamic and Confucian societies, can be traced to their cultures. He argues that such societies will not only reject western civilization, but that they will develop their own economic and military capabilities through cooperation with each other. But why should the nonwestern world "join" the West, especially when "join," in Huntington's dictionary, means "dependent" or "servant" of the West, not 
its "equal." Therefore, the rest of the world does not have to join but has to accept western hegemony.

Huntington's argument that the West constitutes a homogeneous entity has been proven untrue, to a certain degree, with the demise of the Cold War. A glance at the present situation of the West will help us understand the argument.

\section{The West after the Cold War}

Modem western history, particularly that of western Europe, is full of disputes and conflicts. During this century alone, the West has initiated two world wars, which were fought viciously on the lands of nonwestern peoples. It has also been involved in other conflicts around the world. Such conflicts were part of the Cold War or due to disputes over borders created previously by European colonial powers.

It is true that western Europe established institutions that promoted cooperation and eliminated conflict. During the late 1950s, the European Economic Community was established primarily to promote peace and to avoid major conflicts, especially the traditional German-French conflict that had sometimes grown into international conflicts. Its political and economic success was most obvious during the Cold War, when its members had a common enemy: the Soviet Union. But with communism's collapse in eastern Europe and the Soviet Union, it became obvious that the goal of total political unity among member countries was not possible in the absence of a common enemy. The collapse of communism was the beginning of an age of competition among industrialized western states eager to profit from the newly opened ex-communist markets. Therefore, the Treaty of Maastricht faced tremendous opposition in many European countries and almost caused the collapse of some governments.

The United States and Europe have alse engaged in trade wars. The United States and France have been fighting over certain policies of the General Agreement on Tariffs and Trade (GATT). French farmers, as well as Paris, have viewed GATT as a tool of American exploitation and uneven trade. Washington is also facing difficulties from Congress in ratifying the North American Free Trade Agreement (NAFTA). With the election of a new liberal government in Canada, the United States has had to renegotiate the treaty in order to meet new Canadian concerns that parts of the treaty need further discussion.

Europe also has witnessed a resurgence of racist movements in Germany and France. On 20 September 1993, the London-based newspaper The Guardian predicted that the real racist face of Europe will be unmasked during the elections for the Members of the European Parliament (MEL), which will be held during the summer of 1994. The article also stated that far right groups in Europe have been gaining popular support 
and are victors in elections. At present, there are ten members from the French National Front, three from Germany, and one from Belgium in the European Parliament. On the national level, the French National Front has gained 12.5 percent of the popular vote but still has not won any seats. However, in the 1992 local elections it gained 13.9 percent and won 239 regional council seats. It also has $\mathbf{8 0 4}$ municipal councilors. In Italy, the far right Movimento Sociale Italino-Destra Nationale won 34 seats in the 1992 national elections and, for the first time since 1945 , took control of nine small community councils. The Vlaams Blok in Belgium won twelve seats in the Chamber of Representatives and five in the Senate with 6.6 percent of the vote in the 1991 general elections. It is obvious that these racist sentiments were unleashed by the European Community's recession.

The collapse of the Soviet Union has caused Europeans to retreat to a pre-Second World War mentality. One aspect of Europe's intentional failure to solve the Bosnian problem can be blamed on alliances formed during the Second World War. The British position, as well as most of the members of the European Community, is to try to solve the problem peacefully and, at the same time, to reward the aggressors by dividing the country into three ethnic states. London's actions are based on the fact that the Serbs were, and continue to be in the "New World Order," as anti-German and pro-British as they were during the Second World War. In other words, Europe is going back to its old alliances and enemies, which will most likely result in additional conflict in the future.

Some western scholars, among them Huntington, played a major role for the West by setting the world's stage so that it could conduct its foreign policy. They have seen a new ideological enemy on the horizon: Islam. Thus the West has justified its Bosnian policy by claiming that the conflict is a civil war among the ethnic groups of the former Yugoslavia and that no outside force should intervene. In reality, however, it considers a Muslim majority Bosnian state-an "Islamic state in the heart of Europe" - unacceptable.

Some view such a state as an open door for the penetration of Europe by Islamic fundamentalism. In September 1992, a report entitled "Iran's European Springboard?" was authored by the Task Force on Terrorism and Unconventional Warfare and published by the United States House Republican Research Committee. One conclusion reached was that the Bosnian government of Alija Izetbegovic wants to establish an Islamic republic in the Balkans as part of an international Islamic conspiracy.

At the center of the Iranian system in Europe is BosniaHerzegovina's president, Alija Izetbegovic, 'a fundamentalist Muslim and a member of the Fida 'ian-e Islam organization,' who is committed to the establishment of an Islamic Republic in Bosnia-Herzegovina. 
The report also accuses Iran of sending Islamist terrorists into Bosnia to prepare for a general Muslim uprising in western Europe. ${ }^{1}$

My argument that the war in Bosnia is a religious conflict is supported by Senator Joseph Biden. After visiting Sarajevo in early 1993, he criticized severely the European position, which he attributed to the fact that European foreign policy is influenced deeply by religion. Moreover, Biden argued that if Muslims were engaged in ethnic cleansing operations against Christians, the European policy would have been different.

\section{What Needs to Be Done to Avoid Interwestern Conflict}

After going around in circles for twenty-eight pages, Huntington reveals the real thrust of his article. He offers strategies for the West on how to deal with the rest of the world, especially those chosen by Huntington and others to assume the old Soviet position and become the new enemy. Huntington's strategies do not call on the West to understand, compromise, and accommodate others, but to confront, conquer, and control nonwestern civilizations, especially the Muslim world. His short-term strategies are designed to strengthen the already strong, dominant West. He suggests cooperation among westem nations and enlarging its membership through the addition of eastern Europe and North America. To ensure western supremacy and nonwestern division, Huntington recommends that the West "exploit differences and conflicts among Confucian and Islamic states." The "New West" also should "limit the expansion of the strength of Confucian and Islamic states." Despite the fact that he has set the stage for his antagonists and protagonists, he claims that his intent "is not to advocate the desirability of conflicts between civilizations."

It is obvious that western security concerns during the Cold War were the glue that kept the West united. However, Huntington has found a new glue to assure continuous western hegemony. Instead of using the politically loaded term "religion" as the basis for future conflict, he uses the neutral term "civilization." But if one reads between the lines, one can see that he is calling for unity among the Christian nations of the world.

Mohammed M. Karabal Assistant Professor Department of Political Science International Islamic University Selangor, Malaysia on Bosnia Report," The Washington Report on Middle East Affaris, July/August 1993. 